\title{
Commentary
}

\section{The Mauritius Oil Spill: What's Next?}

\author{
Davide Seveso $^{1,2}\left(\mathbb{D}\right.$, Yohan Didier Louis ${ }^{2, *}\left(\mathbb{D}\right.$, Simone Montano ${ }^{1,2} \mathbb{C}^{\text {, Paolo Galli }}{ }^{1,2}$ and Francesco Saliu ${ }^{1}$ \\ 1 Department of Earth and Environmental Sciences (DISAT), University of Milano, \\ Bicocca, Piazza della Scienza, 20126 Milano, Italy; davide.seveso@unimib.it (D.S.); \\ simone.montano@unimib.it (S.M.); paolo.galli@unimib.it (P.G.); francesco.saliu@unimib.it (F.S.) \\ 2 MaRHE Center (Marine Research and High Education Center), Magoodhoo Island, Faafu Atoll, \\ Nilandhoo 12050, Republic of Maldives \\ * Correspondence: yohanlouis20@gmail.com; Tel.: +39-026-448-2813
}

check for

updates

Citation: Seveso, D.; Louis, Y.D.; Montano, S.; Galli, P.; Saliu, F. The Mauritius Oil Spill: What's Next? Pollutants 2021, 1, 18-28. https:// doi.org/10.3390/pollutants1010003

Received: 30 November 2020

Accepted: 26 January 2021

Published: 2 February 2021

Publisher's Note: MDPI stays neutral with regard to jurisdictional claims in published maps and institutional affiliations.

Copyright: (c) 2021 by the authors. Licensee MDPI, Basel, Switzerland. This article is an open access article distributed under the terms and conditions of the Creative Commons Attribution (CC BY) license (https:// creativecommons.org/licenses/by/ $4.0 /)$.

\begin{abstract}
In light of the recent marine oil spill that occurred off the coast of Mauritius (Indian Ocean), we comment here the incident, the containment method used by the local population, the biological impact of oil spill on two sensitive tropical marine ecosystems (coral reefs and mangrove forests), and we suggest monitoring and restoration techniques of the impacted ecosystems based on recent research advancements.
\end{abstract}

Keywords: oil spill; mitigation; restoration; PAHs; Mauritius; marine ecosystem; marine pollution; coral reef; mangrove

\section{The MV Wakashio Accident: Consequences and First Containment Measures}

On 25 July, a $300 \mathrm{~m}$ long Japanese tanker that was sailing without cargo from China to Brazil, named MV Wakashio, ran aground on a barrier reef off the south-east coast of Mauritius (location Pointe d'Esny). According to official statements, MV Wakashio had on board around 4200 metric tons (MT) of fuel for its own consumption, including low-sulphur fuel oil (3894 MT), diesel (207 MT), and lubricant oil (90 MT) [1]. Inhabitants of the south east of Mauritius and fishermen promptly expressed their concern about the socio-economic and environmental consequences on the incident [2]. The national oil contingency plan was activated by the Ministry of Environment, Solid Waste Management, and Climate Change on the day of the ship's grounding and oil booms were installed [3]. Unfortunately on 7 August the MV Wakashio began leaking its engine fuel [4] (Figure 1).

Mauritius declared a "state of environmental emergency" on the same day and requested international help. Local authorities indicated that approximately $3000 \mathrm{MT}$ of fuel was pumped out before the ship broke in two, whereas around 1000 MT leaked into the sea [5]. The local population, non-govermental organizations (NGOs), and community service groups reacted promptly and actively participated in different ways to limit the oil spill spread, by using different artisanal methods to contain the spill and in the removal operations of oil from the sea surface and along the coastline (Figure 2). By 24 August, 1122 tons of contaminated liquid waste (oil mixed with seawater) and 792 tons of contaminated solid on the shore has been carted away [6]. Clean-up operations are still ongoing in areas difficult of access such as mangroves swamps. Although the MV Wakashio oil spill is considerably smaller in terms of volume of oil spilled compared to previous oil spills disaster (e.g., 220,880 MT leaked from the sinking of the Amoco Cadiz, off the coast of Brittany, France in 1978, and more recently, on April 2010, 4.9 million barrels of crude oil were released into the Gulf of Mexico after the Deepwater Horizon drilling platform explosion), it has affected three highly ecologically sensitive sites of one of the most renowned coral reef of the word, and therefore has brought severe economic impacts to the local communities that reply on them; (i) The Marine Protected Area of Blue Bay Marine Park; (ii) the nature reserve Ile aux Aigrettes, which is a coral island hosting rare and endemic birds and geckos; and (iii) a mangrove forest protected under the Ramsar Convention. $36 \mathrm{~km}$ of 
shoreline has been declared off limits, and fishing and recreational activity in those areas were banned [7,8]. Recreational activities have been re-authorized in November 2020, but fishing in the impacted areas remains banned [9]. So far, accordingly to local observation, there is no visible trace of crude oil on the sea surface, but large accumulation is still present in the mangroves forest. This may have long-term consequences on the ecosystem. Proper monitoring plans and that restoration counteraction are required, since severe toxicological effects of oil on the marine communities, from the microbial communities to the mammals, have been already detailed by several researches (reviewed in [10]).

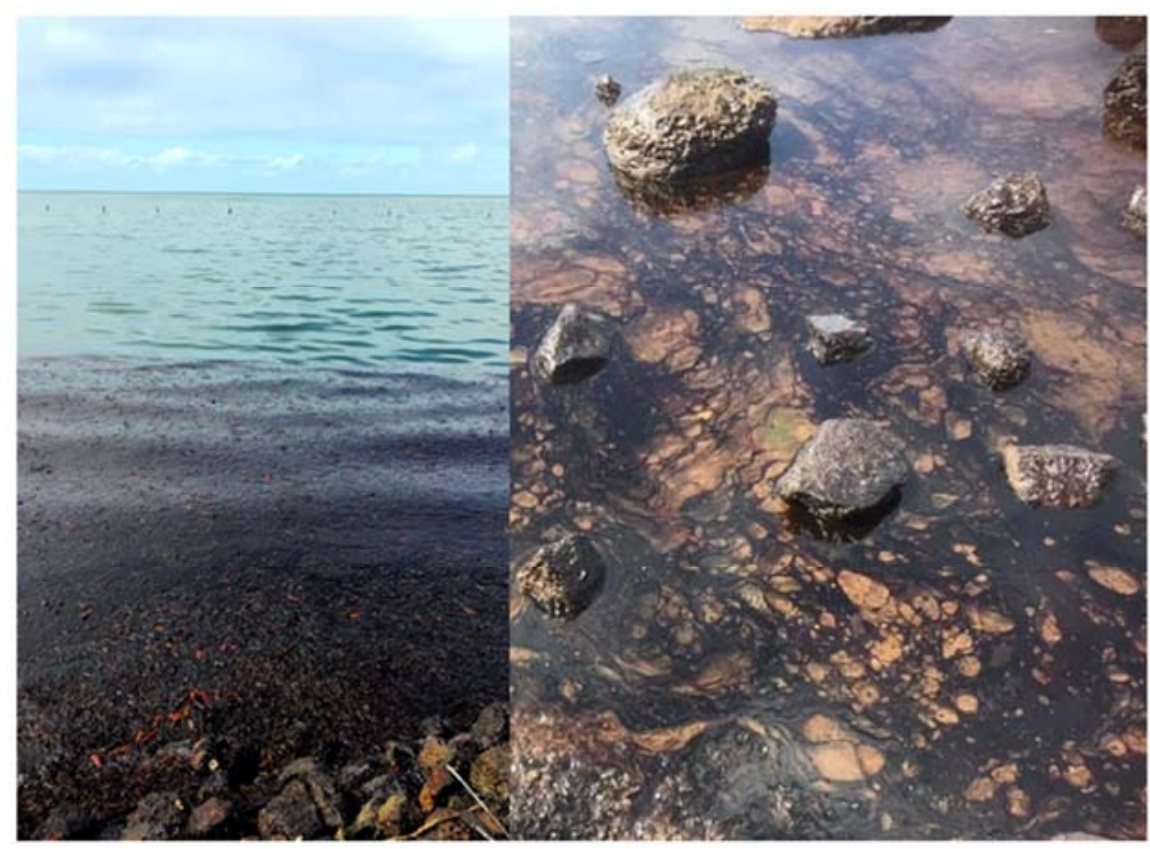

Figure 1. The MV Wakashio oil spill. In the first photo on the left, oil leaked from the ship reaching the South-east coast of Mauri-tius. On the left, close-up view of the oil spots on the sea surface (Credits: Yohan Didier Louis). 


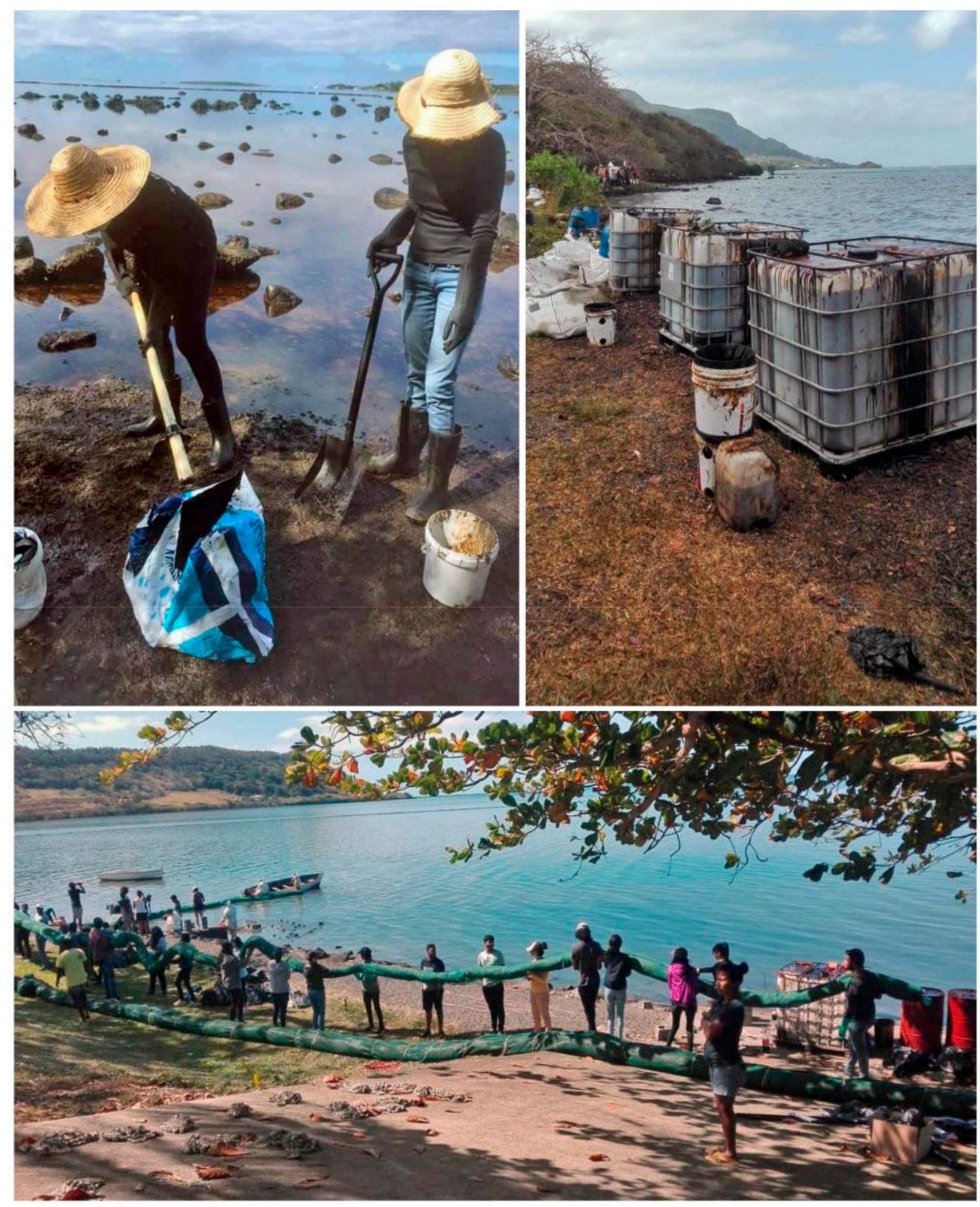

Figure 2. Citizens of Mauritius helping to fight the oil spill by collecting the spilled oil by accumulating on their beaches and by deploying artisanal booms made of dried sugarcane leaves (Credits: Yohan Didier Louis and Rima Beesoo).

\section{Impacts of the Oil Spill on Marine Communities}

The oil toxicity is mainly due to the aromatic hydrocarbons, particularly polycyclic aromatic hydrocarbons (PAHs), which show binding ability to DNA and protein, low water solubility, liphophilicity, and high persistence. Carcinogenic and long-term chronic impacts have been reported even when these compounds were exposed at low levels to marine organisms [11,12]. The oil spill in Mauritius has affected sensitive ecosystems such as mangroves (Figure 3). The consequence for marine life could be disastrous as mangroves are the nursery of the marine environment. Mangrove communities are particularly susceptible to damage from large oil spills [13-16]; when oil is released into coastal waters 
and washed ashore, it deposits on sediments that cover the highly sensitive fine feeding roots of mangrove trees. Once deposited, oil adheres and rarely moves, having adsorbed to oleophilic surfaces of plants. Oil coats the breathing surfaces of mangrove roots, stems, seedlings, and surrounding sediments, as well as fauna present in burrows and root hollows (Figure 3). When smothered with oil, shorter plants and animals die mostly within days. By contrast, taller mature trees and shrubbery, oiled only on their exposed roots and sediments, might persist for six or more months before dying [17]. The effects of oil spills on mangrove communities are reviewed in [17].

Together with mangrove, filter feeders, such as corals and crustaceans and mollusks, are of particular concern. Crabs are mostly exposed to oil toxicity through coating on surfaces and body suffocating, feeding on oil polluted sediments, which causes ensnaring and blockage of the gills, and low feeding [18,19]. Heavy coating of oil on the crab's body has detrimental impact, such as impaired physiology and behavior, interfering ecosystem roles, and transferring to crab predators. Various research have recorded high death of crabs exposed to oil spills whiles surviving members have impaired movement and digging ability [20]. Among mollusks, mussels and other bivalves accumulate oil for long period through their gills due to their filter feeding activity [21]. The continuous accumulation of oil generates reduction in development and DNA impairment within $48 \mathrm{~h}$ of exposure with a significant increase in this impairment by $72 \mathrm{~h}$ [22]. The cellular immunity of mussels was also disrupted [23,24].

The acute and chronic effects and injuries of oil pollution on coral species, both on the adult colonies and larvae, has been analysed in previous field and experimental studies [25-32]. These studies have confirmed various lethal and sublethal physiological, behavioral, and ecological responses of scleractinians, including impaired reproduction and fecundity, low larval recruitment and survivorship, decreased growth, increased tissue damage, and bleaching [25-32]. The annual mass spawning of corals has been observed in the impacted area at the start of November 2020 similar to previous. The oil spill has hence not altered the timing of the release of gametes for this year, a least. However, no information is yet available on the fertilization, survival, and settlement success of coral planula larvae. In coral reef ecosystem subjected to oil spills, the total coral cover and the species diversity showed a significant decline, leading to substantial changes of the community structure being detectable up to several years after the spill [33-37]. In addition, deep-water coral communities were also found affected by oil spill events, and many large octocoral colonies below the oil slick exhibited significantly more injury than in years before the spill [38-42].

Fish at early life stages (eggs and larvae) are highly susceptible to PAHs due to the lack of developed cell membranes and detoxification structures [43] and may face malformation, circulatory failure, stunted development, and low appetite [44,45]. In adult fishes, PAHs may a cause reduced feeding and growth rates, increase vulnerability to predators and starvation [46,47], loss of hatching ability of eggs, fouling of gill structures, impaired reproduction, growth, development, feeding, respiration [48]. PAHs also interrupt the normal development and role of the heart, which can further cause failure of circulation [44,49]. Noteworthy, significant changes in fish community structure, especially in term of food web and trophic relationships, as well as a substantial decline in the abundance of demersal reef fish immediately after an oil spill event, have been observed [50,51].

Finally, marine mammals are mostly exposed to oil on the sea surface and shoreline. Dolphins and whales, as well as sea turtles, are mostly affected by oil spills since they breathe at sea surface and ingest oil after an oil spill, resulting in respiratory irritation, inflammation, emphysema/pneumonia, gastrointestinal inflammation, ulcers, bleeding, diarrhea, and may cause damage to organs [52-54]. Analysis of live bottlenose dolphin exposed to oil showed that they had lung and adrenal ailments coupled with other poor health disorders $[55,56]$. Other research confirmed the vulnerability of the dolphins to bacterial infections and other health ailment that could possibly lead to death $[57,58]$. In this context, almost 20 days after the oil spill, 51 melon-head dolphins were washed up 
in the Mauritius on the shores in the same region where the oil spill occurred. During their necrosis, no traces of hydrocarbon was found on their skin, in the digestive and respiratory tract of the animals, and therefore no direct link with oil spill was found yet $[59,60]$. However, further toxicological analysis revealed the presence of hydrocarbon in 11 of the dead dolphins [60].

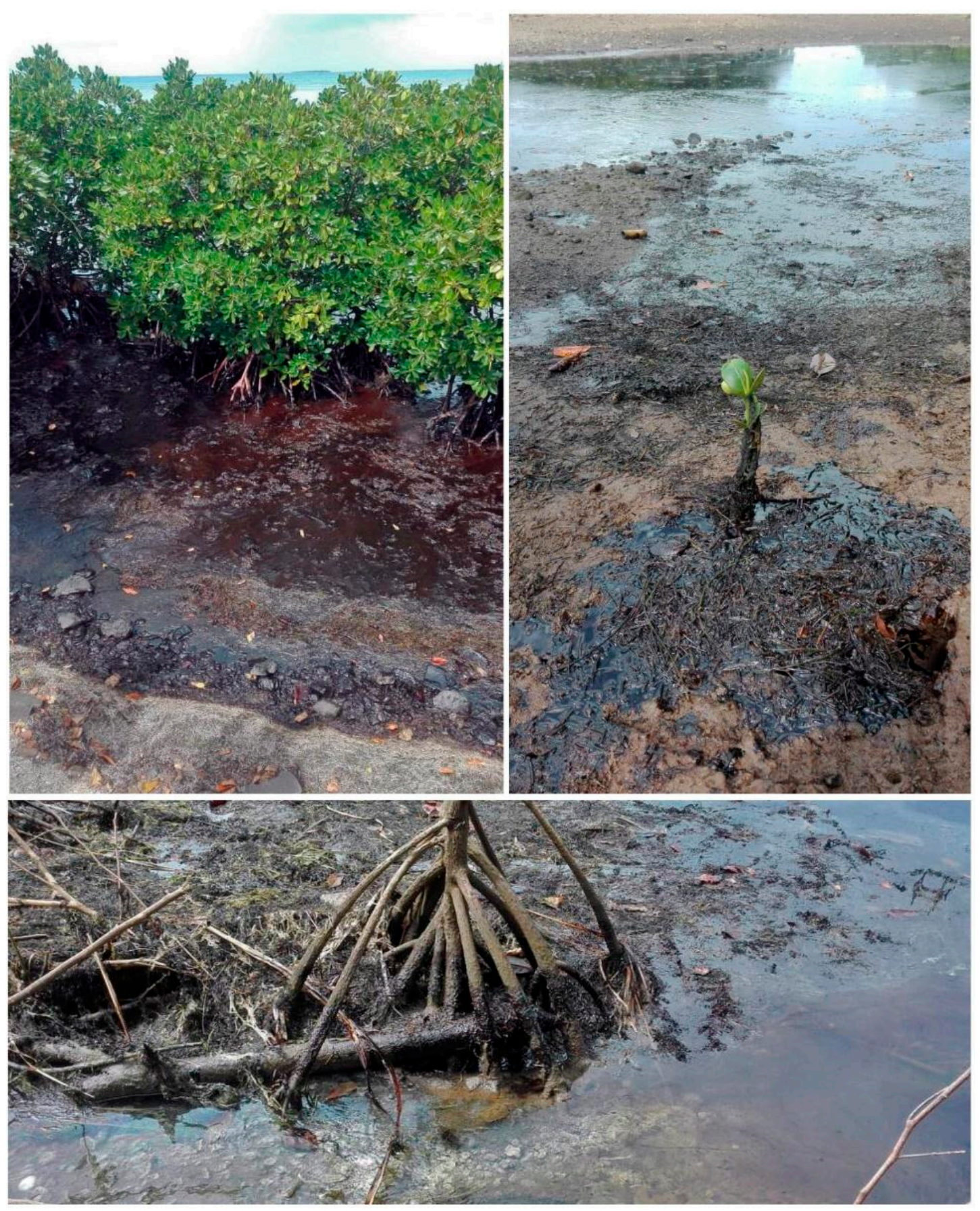

Figure 3. The oil spill has heavily affected the mangroves forest. Large and dense oil stains cover the shallow basin where the trees develop and affect a young mangrove propagule as well as the mangrove roots (Credits: Yohan Didier Louis). 


\section{Short- and Long-Term Mitigation Measures}

To have an overview of the impact and the damage caused by the oil spill on the ecosystem biodiversity by the ecological approach, as well as the incidence of the oil spill on the different biota and within each biota, the prevalence of the impact at population and community level must be measured. In addition, at the organism level, since the earliest steps of an individual's response to any environmental stress occur at the cellular level, a useful diagnostic tool is the analysis of the expression of cellular and molecular biomarkers (such as stress proteins, enzymes, and gene expression) that reflect changes in cellular structural integrity, as well as in functional cellular pathways and performance. Hierarchically, the organism's physiology is the nexus between the organism and the stressor, playing a paramount role in determining their tolerance and resilience to stressors.

In this context, the efforts to remove the oil should have for first aim the recovery of a healthy biological community. According to ITOPF (International Tanker Owners Pollution Federation) indication [61], clean-up operation may be delivered following a two stage process: firstly, the prompt removal of the gross contamination, and after that, targeted activities to limit the pollution damage and help the natural healing process. Moreover, it should always be taken into account that nature play the very large part in the cleaning process and that improper clean-up operations may cause additional damage beyond that caused by the oil spill (such as an excessive use of hot water and chemicals to reach a fast and unrealistic last oil drop removal).

The removal of free oil from mangrove stand using a low-pressure high volume of water has already been reported in order to mitigate long-term damage. The use of heavy vehicles and excessive manpower should be monitored in order to avoid damages to rootstocks by trampling. In addition, the chemical and physical characteristics of the oil should be also taken into account, as light refined oils, such as diesels, are less persistent, but more toxic and should be removed firstly from sensitive sites. On the contrary, higher viscosity oil can stick and persist for a longer time, with the possibility that the recovery of the original ecological features of the habitats and ecosystems are reached even without a visible cleanliness of the area.

To the best of our knowledge, dispersants were not applied following the oil spill. The effectiveness of dispersants to combat oil spill is highly debated in the literature and current reviews focus on the fact that their application should be tailored considering environmental conditions, the chemical profile of the spilled oil, and also possible counteraction with other clean-up operations. From an ecological point of view, the fact that the oil is removed from the sea surface and moved again to the water column in the form of little droplets can cause more risks, as corals, seagrasses, and fish larvae may be more readily affected. Moreover, even free swimming fish should not be considered safe, as they are able to spot and avoid large oil bulky mass, but not the tiny dispersed droplets.

In a study conducted following an oil spill event in Panama, the short- and long-term effects of floating oil and chemically dispersed oil on mangroves, seagrasses, and corals in sheltered shallow sea areas, similar to those of Mauritius, were analyzed [62]. The study concluded that the dispersed oil initially caused large mortality to invertebrate fauna and seagrass beds and reduced coral cover by approximately $30 \%$. However, within 10 years, the coral coverage had fully recovered to pre-spill levels. In addition, floating oil significantly affected the mangrove forests, with $46 \%$ mortality of the adult mangroves and evident signs of coastal erosion. In this case, 20 years after the initial oiling, no significant evidence of recovery of the mangrove forests was detected, as adult mangrove trees were still dying, although new trees were slowly replacing those killed by the oil [62]. Others post-spill assessments suggest that structural recovery of oil-damaged mangrove forests takes place over a period of at least three decades [17]. 


\section{Monitoring and Restoration of Coral Reef and Mangrove Forests}

In Mauritius, monitoring of health of mangroves and corals communities started soon after most of the spilled oil had been recovered. Different specialised working groups were set up by the Government consisting of Government officers, university researchers, and scientists from NGOs, and also foreign scientists notably from Japan and the United Nations $(\mathrm{UN})$. The aim of this working group was to regroup scientists with relevant expertise and local field experience to start a coordinated preliminary ecological monitoring soon after the catastrophe. Monitoring is still on-going.

Coral and mangrove farming and restoration may represent the best, and maybe the only, solution in order to try to restore the pre-oil spill condition and the functionality of coral reefs and mangrove forests, two fundamental marine habitats that provide several ecosystem services to the Mauritian population.

The concept of restoration is connected to that of rehabilitation [63] and it implies "assisting the recovery of an ecosystem that has been degraded, damaged, or destroyed". To date, coral restoration is still a discipline in development, with a lot of research currently being done to address those challenges and to improve and innovate on the techniques used. Different techniques exist and may be used to enhance the Mauritian coral reefs. Coral transplantation may be used to translocate corals, in whole or in parts, to a denuded or degraded reef, for example, affected by the oil spill [64]. Coral transplantation can be considered particularly effective in the case of physical damages (such as ship groundings or hurricanes) due to the large availability of coral fragments. In the most damaged reefs, artificial reefs can be used aimed at rehabilitating denuded and structurally unstable areas to promote the settlement of various invertebrates. Some examples are represented by Reef Balls ${ }^{\mathrm{TM}}$ [65], which are ball-like hollow elements; Coral Spiders, which are metal modules and have been used in a successful project in an Indonesian island [66] to consolidate rubble; or sand-coated metal frames [67], used in sandy environments. However, coral gardening is now one of the most used methods for coral propagation. It is represented by the creation of in situ nurseries (rope nurseries or table nurseries) to grow coral colonies from fragments in areas within the reef, but not affected by human pressure, sedimentation, wave action, and predators [67-69]. On these structures, corals grow to a size suitable to then be transplanted on reefs, including artificial reefs.

Different techniques have also been developed to restore mangrove forests [70-73], and could thus potentially be used for those in Mauritius affected by oil release. Moreover, the operational response guidelines based on actions and response strategies for monitoring and restore mangrove habitats impacted by large oil spills were well developed as Standard Operational Procedures [17]. The types of responses, actions, and their timing depend on four threat phases of the spill incident: "Pre-Spill", "During Spill Pre-Impact" and "During Spill Post-Impact", and "Post Spill". For each phase, specific action and monitoring plans are developed and suggested [17].

Mangrove planting is the most common method of restoring mangrove forests. It basically consists of planting new seedlings or propagules or adult trees in the degraded area previously occupied by the forest. However, work must not be focused only on techniques for growing mangrove trees (a "tree-centered approach"), as attention must be paid to long-term community structure [70]. In addition, the approach is not often successful, especially when the reasons for mangrove degradation were not removed prior to planting. For example, in a previous study, a detached breakwater was erected seaward at the shoreline to shelter the restoration area from wave action; prevent the ongoing erosion; and promote sediment deposition, raising the elevation of the substrate to the target elevation [73].

Currently, in Mauritius, different restoration techniques have been proposed by NGOs. These include mangrove and coral farming to restore the respective ecosystems, but to date, discussions are still on-going for a coordinated and efficient restoration program. 


\section{Conclusions}

Mauritius is one of the most renowned coral reef of the planet, comprising a wide marine protected area rich in biodiversity, estimated by travelers from all around the word as paradise for leisure, sightseeing, scuba diving, and water sports. Unfortunately, the islands lie near a shipping highway used by thousands of large vessels every year. This represents a hazard for their natural treasures, which the MV Wakashio accident confirmed to be real. Thanks to recent research advancement, the scientific community has gained knowledge about the impacts of oil spill on marine ecosystem, and developed technologies that may limit the ecological damage in the short term and speed up natural self-healing processes in the long term. However, the large differences in the time scale of the events (accident-response-restoration) as well as the irreversibility of a part of the pollution process are, once again, under our eyes; the spill was spread in a few weeks after the vessel ground, the assessment of the impacts on the marina fauna and the action to restore the affected ecosystem are still (after several months) in progress, and will most probably continue for years.

Author Contributions: Conceptualization, P.G. and F.S.; Methodology, D.S. and F.S.; Resources, Y.D.L.; Data Curation, F.S.; Writing-Original Draft Preparation, D.S, Y.D.L., S.M. and F.S.; WritingReview \& Editing, D.S., Y.D.L., S.M. and F.S.; Supervision, F.S. and P.G.; Project Administration, F.S. All authors have read and agreed to the published version of the manuscript.

Funding: This research received no external funding.

Conflicts of Interest: The authors declare no conflict of interest.

\section{References}

1. United Nations Office for the Coordination of Humanitarian Affairs (OCHA). Mauritius: MW Wakashio Oil Spill. Flash Update No 1. 2020. Available online: https:/ / reliefweb.int/report/mauritius/mauritius-mw-wakashio-oil-spill-flash-update-no-1-8august-2020 (accessed on 10 October 2020).

2. Deena, M.; Ramkhelawon, D.; Mudhoo, S.; Boyjonauth, N.D. Des Habitants du Sud Remontés Contre la Carence des Autorités L'express. 2020. Available online: https://www.lexpress.mu/video/380812/habitants-sud-remontes-contre-carence-autorites (accessed on 13 October 2020).

3. Republic of Mauritius, Parliamentary Debates (Hansard), National Assembly. 28 July 2020. Available online: https:// mauritiusassembly.govmu.org/Documents/Hansard/2020/hansard272020.pdf (accessed on 12 October 2020).

4. The Guardian. Mauritius Facing Environmental Crisis as Shipwreck Leaks Oil. The Guardian, 7 August 2020. Available online: https:/ / www.theguardian.com/world/2020/aug/07/mauritius-facing-environmental-disaster-after-striken-bulk-carrierleaks-oil(accessed on 15 October 2020).

5. Bearak, M. Rough Seas Are Hampering Response to Mauritius Ship Leak; Oil Spill Reaches 1,000 tons. The Washington Post, 9 August 2020. Available online: https:/ / www.washingtonpost.com/world/africa/mauritius-oil-spill-wakashio/2020/08/09/8 dd09ee8-da49-11ea-b205-ff838e15a9a6_story.html(accessed on 15 October 2020).

6. The National Crisis Committee. Update on Wakashio Vessel as at 4pm on Monday August 24. 2020. Available online: https: / / environment.govmu.org/Documents/wakashio/Press \%20Release \%20FINAL \%20Wakashio\%20as \%20at\%204PM \%20 on\%20Monday\%20August\%2024,\%202020.pdf (accessed on 15 October 2020).

7. Ministry of Blue Economy, Marine Resources, Fisheries and Shipping. Fish Analysis-MV Wakashio [Communique, 8 September 2020]. Available online: https://govmu.org/EN/Communique1/communique-fisheries.pdf (accessed on 15 October 2020).

8. The Government Gazette of Mauritius (Extraordinary). The National Disaster Risk Reduction and Management Act. General Notice, No. 1148. 2020. Available online: https://environment.govmu.org/Documents/wakashio/Restricted\%20Areas\%20in\% 20the\%20SE\%20Region.pdf (accessed on 14 November 2020).

9. The National Crisis Committee. Leve D'interdiction Concernant Activites Nautiques lor la Cote Sud-est. Communique. 6 November 2020. Available online: https://drive.google.com/file/d/18W5ME06hbmXd-knGs7SqugWG8vhbPhol/view (accessed on 15 November 2020).

10. Adzigbli, L.; Yuewen, D. Assessing the impact of oil spills on marine organisms. J. Oceanogr. Mar. Res. 2018, 6. [CrossRef]

11. Neff, J.M. Bioaccumulation in Marine Organisms: Effect of Contaminants from Oil Well Produced Water; Elsevier: Amsterdam, The Netherlands, 2002.

12. Lin, C.Y.; Tjeerdema, R.S. Crude oil, oil, gasoline and petrol. In Ecotoxicology; Elsevier: Amsterdam, The Netherlands, 2008.

13. Proffitt, E.C. (Ed.) Managing Oil Spills in Mangrove Ecosystems: Effects, Remediation, Restoration, and Modeling; OCS Reports; Gulf of Mexico OCS Region, Minerals Management Service, U.S. Department of the Interior: New Orleans, LA, USA, 1997 ; Volume 97. 
14. Hensel, P.; Proffitt, E.C.; Delgado, P.; Shigenaka, G.; Yender, R.; Hoff, R.; Mearns, A.J.; Hoff, R. (Eds.) Oil Spills in Mangroves Planning and Response Considerations; National Oceanic and Atmospheric Administration: Washington, DC, USA, 2010.

15. Lewis, M.; Pryor, R.; Wilking, L. Fate and effects of anthropogenic chemicals in mangrove ecosystems: A review. Environ. Pollut. 2011, 159, 2328-2346. [CrossRef] [PubMed]

16. Santos, H.F.; Carmo, F.L.; Paes, J.E.; Rosado, A.S.; Peixoto, R.S. Bioremediation of mangroves impacted by petroleum. Water Air Soil Pollut. 2011, 216, 329-350. [CrossRef]

17. Duke, N.C. Oil spill impacts on mangroves: Recommendations for operational planning and action based on a global review. Mar. Pollut. Bull. 2016, 109, 700-715. [CrossRef] [PubMed]

18. Culbertson, J.B.; Valiela, I.; Peacock, E.E.; Reddy, C.M.; Carter, A.; Vander Kruik, R. Long-term biological effects of petroleum residues on fiddler crabs in salt marshes. Mar. Pollut. Bull. 2007, 54, 955-962. [CrossRef] [PubMed]

19. Kristensen, E. Mangrove crabs as ecosystem engineers; With emphasis on sediment processes. J. Sea. Res. 2010, 59, 30-43. [CrossRef]

20. Krebs, C.T.; Burns, K.A. Long-term effects of an oil spill on populations of the salt-marsh crab Uca pugnax. Science 1977, 197, 484-487. [CrossRef]

21. Culbertson, J.B.; Valiela, I.; Olsen, Y.S.; Reddy, C.M. Effect of field exposure to 38-year-old residual petroleum hydrocarbons on growth, condition index, and filtration rate of the ribbed mussel, Geukensia demissa. Environ. Pollut. 2008, 154, 312-319. [CrossRef]

22. Banni, M.; Negri, A.; Dagnino, A.; Jebali, J.; Ameur, S.; Boussetta, H. Acute effects of benzo [a] pyrene on digestive gland enzymatic biomarkers and DNA damage on mussel Mytilus galloprovincialis. Ecotoxicol. Environ. Saf. 2010, 73, 842-848. [CrossRef]

23. Hanman, M.L.; Bamber, S.D.; Galloway, T.S.; Moody, J.A.; Jones, M.B. Effects of the model PAH phenanthrene on immune function and oxidative stress in the haemolymph of the temperate scallop Pecten maximus. Chemosphere 2010, 78, 779-784.

24. Croxton, A.N.; Wikfors, G.H.; Schulterbrandt-Gragg, R.D. Immunomodulation in eastern oysters, Crassostrea virginica, exposed to a PAH-contaminated, microphytobenthic diatom. Aquat. Toxicol. 2012, 118, 27-36. [CrossRef] [PubMed]

25. Guzmán, H.M.; Holst, I. Effects of chronic oil-sediment pollution on the reproduction of the Caribbean reef coral Siderastrea siderea. Mar. Pollut. Bull. 1993, 26, 276-282. [CrossRef]

26. Negri, A.P.; Heyward, A.J. Inhibition of fertilization and larval metamorphosis of the coral Acropora millepora (Ehrenberg, 1834) by petroleum products. Mar. Pollut. Bull. 2000, 41, 420-427. [CrossRef]

27. Scarlett, A.; Galloway, T.S.; Canty, M.; Smith, E.L.; Nilsson, J.; Rowland, S.J. Comparative toxicity of two oil dispersants, superdispersant-25 and corexit 9527, to a range of coastal species. Environ. Toxicol. Chem. 2005, 24, 1219-1227. [CrossRef] [PubMed]

28. Downs, C.A.; Richmond, R.H.; Mendiola, W.J.; Rougée, L.; Ostrander, G.K. Cellular physiological effects of the MV Kyowa Violet fuel-oil spill on the hard coral, Porites lobata. Environ. Toxicol. Chem. 2006, 25, 3171-3180. [CrossRef]

29. Shafir, S.; Van Rijn, J.; Rinkevich, B. Short and long term toxicity of crude oil and oil dispersants to two representative coral species. Environ. Sci. Technol. 2007, 41, 5571-5574. [CrossRef]

30. Goodbody-Gringley, G.; Wetzel, D.L.; Gillon, D.; Pulster, E.; Miller, A.; Ritchie, K.B. Toxicity of Deepwater Horizon source oil and the chemical dispersant, Corexit ${ }^{\circledR}$ 9500, to coral larvae. PLoS ONE 2013, 8, e45574. [CrossRef]

31. Hartmann, A.C.; Sandin, S.A.; Chamberland, V.F.; Marhaver, K.L.; de Goeij, J.M.; Vermeij, M.J. Crude oil contamination interrupts settlement of coral larvae after direct exposure ends. Mar. Ecol. Prog. Ser. 2015, 536, 163-173. [CrossRef]

32. Negri, A.P.; Brinkman, D.L.; Flores, F.; Botté, E.S.; Jones, R.J.; Webster, N.S. Acute ecotoxicology of natural oil and gas condensate to coral reef larvae. Sci. Rep. 2016, 6, 21153. [CrossRef]

33. Loya, Y.; Rinkevich, B. Effects of oil pollution on coral reef communities. Mar. Ecol. Prog. Ser. 1980, 3, 180. [CrossRef]

34. Guzmán, H.M.; Jackson, J.B.; Weil, E. Short-term ecological consequences of a major oil spill on Panamanian subtidal reef corals. Coral Reefs 1991, 10, 1-12. [CrossRef]

35. Guzmán, H.M.; Burns, K.A.; Jackson, J.B. Injury, regeneration and growth of Caribbean reef corals after a major oil spill in Panama. Mar. Ecol. Prog. Ser. 1994, 105, 231-241. [CrossRef]

36. Guzman, H.M.; Kaiser, S.; Weil, E. Assessing the long-term effects of a catastrophic oil spill on subtidal coral reef communities off the Caribbean coast of Panama (1985-2017). Mar. Biodiv. 2020, 50, 1-19. [CrossRef]

37. Haapkylä, J.; Seymour, A.S.; Trebilco, J.; Smith, D. Coral disease prevalence and coral health in the Wakatobi Marine Park, south-east Sulawesi, Indonesia. J. Mar. Biol Assoc. UK 2007, 87, 403-414. [CrossRef]

38. White, H.K.; Hsing, P.Y.; Cho, W.; Shank, T.M.; Cordes, E.E.; Quattrini, A.M.; Nelson, R.T.; Camilli, R.; Demopoulos, A.W.J.; German, C.R.; et al. Impact of the Deepwater Horizon oil spill on a deep-water coral community in the Gulf of Mexico. Proc. Natl. Acad. Sci. USA 2012, 109, 20303-20308. [CrossRef]

39. Etnoyer, P.J.; Wickes, L.N.; Silva, M.; Dubick, J.D.; Balthis, L.; Salgado, E.; MacDonald, I.R. Decline in condition of gorgonian octocorals on mesophotic reefs in the northern Gulf of Mexico: Before and after the Deepwater Horizon oil spill. Coral Reefs 2016, 35, 77-90. [CrossRef]

40. Silva, M.; Etnoyer, P.J.; MacDonald, I.R. Coral injuries observed at mesophotic reefs after the Deepwater Horizon oil discharge. Deep Sea Res. Part II 2016, 129, 96-107. [CrossRef]

41. Girard, F.; Shea, K.; Fisher, C.R. Projecting the recovery of a long-lived deep-sea coral species after the Deepwater Horizon oil spill using state-structured models. J. Appl. Ecol. 2018, 55, 1812-1822. [CrossRef] 
42. DeLeo, D.M.; Herrera, S.; Lengyel, S.D.; Quattrini, A.M.; Kulathinal, R.J.; Cordes, E.E. Gene expression profiling reveals deep-sea coral response to the Deepwater Horizon oil spill. Mol. Ecol. 2018, 27, 4066-4077. [CrossRef]

43. Langangen, Ø.; Olsen, E.; Stige, L.C.; Ohlberger, J.; Yaragina, N.A.; Vikebø, F.B.; Bogstad, B.; Stenseth, N.C.; Hjermann, D.Ø. The effects of oil spills on marine fish: Implications of spatial variation in natural mortality. Mar. Pollut. Bull. 2017, 119, 102-109. [CrossRef]

44. Sørhus, E.; Incardona, J.P.; Furmanek, T.; Goetz, G.W.; Scholz, N.L.; Meier, S.; Edvardsen, R.B.; Jentoft, S. Novel adverse outcome pathways revealed by chemical genetics in a developing marine fish. eLife 2017, 6, e20707. [CrossRef] [PubMed]

45. Bellas, J.; Saco-Alvarez, L.; Nieto, O.; Bayona, J.M.; Albaiges, J.; Beiras, R. Evaluation of artificially-weathered standard fuel oil toxicity by marine invertebrate embryogenesis bioassays. Chemosphere 2013, 90, 1103-1108. [CrossRef] [PubMed]

46. Sørhus, E.; Incardona, J.P.; Karlsen, Ø.; Linbo, T.; Sørensen, L.; Nordtug, T.; Van Der Meeren, T.; Thorsen, A.; Thorbjørnsen, M.; Jentoft, S.; et al. Crude oil exposures reveal roles for intracellular calcium cycling in haddock craniofacial and cardiac development. Sci. Rep. 2016, 6, 1-21. [CrossRef] [PubMed]

47. Hicken, C.E.; Linbo, T.L.; Baldwin, D.H.; Willis, M.L.; Myers, M.S.; Holland, L.; Larsen, M.; Stekoll, M.S.; Rice, S.D.; Collier, T.K.; et al. Sublethal exposure to crude oil during embryonic development alters cardiac morphology and reduces aerobic capacity in adult fish. Proc. Natl. Acad. Sci. USA 2011, 108, 7086-7090. [CrossRef] [PubMed]

48. Blackburn, M.; Mazzacano, C.A.S.; Fallon, C.; Black, S.H. Oil in Our Oceans: A Review of the Impacts of Oil Spills on Marine Invertebrates; The Xerces Society for Invertebrate Conservation: Portland, OR, USA, 2014; p. 152.

49. Fodrie, F.J.; Able, K.W.; Galvez, F.; Heck Jr, K.L.; Jensen, O.P.; López-Duarte, P.C.; Martin, C.W.; Turner, R.E.; Whitehead, A. Integrating organismal and population responses of estuarine fishes in Macondo spill research. BioScience 2014, 64, 778-788. [CrossRef]

50. Sulak, K.J.; Dixon, P.M. Change in Gulf of Mexico Mesophotic Reef Fish Community Structure Across the Time Threshold of the DEEPWATER Horizon Oil Spill Event in 2010: Mesophotic Reef Fish Community Impacts of the DWH Oil Spill; DWH Deepwater Benthic NRDA Technical Working Group Report: Montgomery, AL, USA, 2015.

51. Lewis, J.P.; Tarnecki, J.H.; Garner, S.B.; Chagaris, D.D.; Patterson, W.F. Changes in reef fish community structure following the deepwater horizon oil spill. Sci. Rep. 2020, 10, 1-13. [CrossRef]

52. Geraci, J. (Ed.) Sea Mammals and Oil: Confronting the Risks; Elsevier: Amsterdam, The Netherlands, 2012.

53. IPIECA-IOGP. Impacts of Oil Spills on Marine Ecology. Good Practice Guide Series, Oil Spill Response Joint Industry Project (OSR-JIP); IOGP Report Number: 525; The International Association of Oil \& Gas Producers (IOGP): London, UK, 2015.

54. Frasier, K.E.; Solsona-Berga, A.; Stokes, L.; Hildebrand, J.A. Impacts of the Deepwater Horizon Oil Spill on Marine Mammals and Sea Turtles. In Deep Oil Spills; Springer: Cham, Switzerland, 2020; pp. 431-462.

55. Carmichael, R.H.; Graham, W.M.; Aven, A.; Worthy, G.; Howden, S. Were multiple stressors a 'perfect storm'for northern Gulf of Mexico bottlenose dolphins (Tursiops truncatus) in 2011? PLoS ONE 2012, 7, e41155. [CrossRef]

56. Schwacke, L.H.; Smith, C.R.; Townsend, F.I.; Wells, R.S.; Hart, L.B.; Balmer, B.C.; Collier, T.K.; De Guise, S.; Fry, M.M.; Guillette, L.J., Jr.; et al. Health of common bottlenose dolphins (Tursiops truncatus) in Barataria Bay, Louisiana, following the Deepwater Horizon oil spill. Environ. Sci. Technol. 2014, 48, 93-103. [CrossRef]

57. Van Dolah, F.M.; Neely, M.G.; McGeorge, L.E.; Balmer, B.C.; Ylitalo, G.M.; Zolman, E.S.; Speakman, T.; Sinclair, C.; Kellar, N.M.; Rosel, P.E.; et al. Seasonal variation in the skin transcriptome of common bottlenose dolphins (Tursiops truncatus) from the northern Gulf of Mexico. PLoS ONE 2015, 10, e0130934. [CrossRef]

58. Venn-Watson, S.; Colegrove, K.M.; Litz, J.; Kinsel, M.; Terio, K.; Saliki, J.; Fire, S.; Carmichael, R.; Chevis, C.; Hatchett, W.; et al. Adrenal gland and lung lesions in Gulf of Mexico common bottlenose dolphins (Tursiops truncatus) found dead following the Deepwater Horizon oil spill. PLoS ONE 2015, 10, e0126538. [CrossRef]

59. Ministry of Blue Economy, Marine Resources, Fisheries and Shipping. Rapport Préliminaire de L'autopsie des Dauphins Morts sur la Côte sud-est de L'île Maurice. Communique 28 August 2020. Available online: http:/ / mobilisationwakashio.com/2020/08/ 31/ministry-of-blue-economy-marine-resources-fisheries-and-shipping/ (accessed on 13 November 2020).

60. Republic of Mauritius. Parliamentary debates (Hansard), National Assembly. 2 November 2020. Available online: https: / / mauritiusassembly.govmu.org/Documents/Hansard/2020/hansard322020.pdf (accessed on 6 January 2021).

61. International Tanker Owners Pollution Federation. Effects of Oil Pollution on the Marine Environment; Technical Information Paper (TIP) No. 13; International Tanker Owners Pollution Federation: London, UK, 2011.

62. Baca, B.; Ward, A.W.; Lane, H.L.; Schuler, P.A. Net environmental benefit analysis (EBA) of dispersed oil on nearshore tropical ecosystems derived from the 20 year "TROPICS" filed study. In Proceedings Interspill; IOSC: London, UK, 2006.

63. Bradshaw, A.D. What do we mean by restoration. Restor. Ecol. Sustain. Dev. 1997, 10, 8-14.

64. Birkeland, C.; Randall, R.H.; Grimm, G. Three Methods of Coral Transplantation for the Purpose of Re-Establishing a Coral Community in the Thermal Effluent Area at the Tanguisson Power Plant; Marine Laboratory, University of Guam: Mangilao, Guam, 1979.

65. Barber, T.R.; Barber, G.L. Reef Ball. U.S. Patent 5564369, 15 October 1996.

66. Williams, S.L.; Sur, C.; Janetski, N.; Hollarsmith, J.A.; Rapi, S.; Barron, L.; Heatwole, S.J.; Yusuf, A.M.; Jompa, J.; Mars, F. Large-scale coral reef rehabilitation after blast fishing in Indonesia. Restor. Ecol. 2019, 27, 447-456. [CrossRef]

67. Edwards, A.J. (Ed.) Coral Reef Targeted Research \& Capacity Building for Management Program: St Lucia, Australia. In Reef Rehabilitation Manual; Coral Reef Initiative for the South Pacific (CRISP): New Caledonia, France, 2010; p. 166. 
68. Rinkevich, B. Restoration strategies for coral reefs damaged by recreational activities: The use of sexual and asexual recruits. Restor. Ecol. 1995, 3, 241-251. [CrossRef]

69. Rachmilovitz, E.N.; Rinkevich, B. Tiling the reef-exploring the first step of an ecological engineering tool that may promote phase-shift reversals in coral reefs. Ecol. Eng. 1997, 105, 150-161. [CrossRef]

70. Kaly, U.L.; Jones, G.P. Mangrove restoration: A potential tool for coastal management in tropical developing countries. Ambio 1998, 27, 656-661.

71. Ellison, A.M. Mangrove restoration: Do we know enough? Restor. Ecol. 2000, 8, 219-229. [CrossRef]

72. Gilman, E.; Ellison, J. Efficacy of alternative low-cost approaches to mangrove restoration, American Samoa. Est. Coasts 2007, 30, 641-651. [CrossRef]

73. Kamali, B.; Hashim, R. Mangrove restoration without planting. Ecol. Eng. 2011, 37, 387-391. [CrossRef] 